Józef Tymanowski

Uniwersytet Warszawski

\title{
Recenzja wydawnicza książki pt. „Gorbaczow”, autorstwa: Alicji Stępień - Kuczyńskiej, ss. 237
}

$M^{\prime}$ ichaił Gorbaczowa w procesy reformowania ZSRR odegrał istotną role nie tylko W przemianach systemowych tego imperium, ale przede wszystkich, wbrew początkowym jego założeniom pieriestrojka (przebudowa)przyczyniła się do rozpadu państwa i radzieckiego systemu, w skali zaś globalnej do upadku systemu zimnowojennego. Aktywność Gorbaczowa w polityce państwa radzieckiego budzi emocje także w czasach współczesnych, gdy analizujemy przemiany systemowe w Rosji. Warto również podkreślić, że w 2021 roku mija 30 lat od rozpadu ZSRR, którego charakter funkcjonowania stanowi interesujące źródło analiz, zarówno wśród historyków, politologów, jak i socjologów.

O Gorbaczowie, ale i pieriestrojce - jak pisze we Wstępie Alicja Stępień-Kuczyńska do Michait Gorbaczow a idea i praktyka pieriestrojki ( Wydawnictwo Uniwersytetu Łódzkiego, Łódź 2016), - napisano setki książek i artykułów. Każdy kto podejmuje ten temat, staje przed zadaniem niezbędnej selekcji źródet. Na wydarzenia z tamtych lat starałam się patrzeć jako politolog $i$ historyk, przede wszystkim przez pryzmat publikowanych dokumentów, monografii, artykułów i publicystyki. Na ich łamach można śledzić programy, dyskusje, spory, zaś formułowane oceny ukazuja niezwykty obraz z mian w ostatnim etapie istnienia ZSRR ( s.12).

Pozycja wydawnicza Alicji Stępień - Kuczyńskiej „Gorbaczow” jest spopularyzowaną wersja poprzedniej książki o Gorbaczowie i cieszy się dużym zainteresowaniem, nie tylko wśród politologów, ale tej części społeczeństwa, które chce poznać mechanizm władzy państwa radzieckiego, na jego ostatnim etapie działalności.

Recenzowana książka jest niewątpliwie krytycznym, spójnym i logicznie uzasadnionym wywodem naukowym poświęconym przemianom systemowym w ZSRR, którego głównym architektem był M. Gorbaczow. Jest ona publikacją wciąż aktualną, wartościową naukowo i edukacyjnie oraz popularyzatorsko. Jej interesująca i nowatorska, w ujęciu i zastosowaniu metodologii, treść jest adresowana do zainteresowanych zagadnieniami stosunków międzynarodowych, bezpieczeństwa i polityki. 
Wysoko należy ocenić nie tylko konstrukcję książki, ale także jej zawartość merytoryczną.

Warto podkreślić, że na rynku wydawniczym pojawiło się wiele pozycji z zakresu przemian systemowych Federacji Rosyjskiej jak np.: A. Głowacki, A. Kuczyńska - Stępień, Rosja Putina, Wydawnictwo UŁ, Łódź 2004; J. Tymanowski (red.) Federacja Rosyjska w procesie demokratyzacji, Wydawnictwo WDiNP UW, Warszawa 2011; A. Stępień Kuczyńska, M. Słowikowski (red.) Na gruzach imperium, Wydawnictwo Uniwersytetu Łódzkiego, Łódź 2012; A. Stępień - Kuczyńska, Michaił Gorbaczow a idea i praktyka pieriestrojki, Wydawnictwo Uniwersytetu Łódzkiego, Łódź 2016, czy książka pod redakcją J. Tymanowski, A. Skwarski i Natalia Moch, Rosja w procesie wyzwań-miedzy demokracja a autorytaryzmem, Dom Wydawniczy Elipsa, Warszawa 2020.

Treść książki podzielona została na pięć interesujących części nawiązujących do osoby i życia Michaiła Gorbaczowa, jak; rodzina, młodość, u progu polityki; próby reform: przyspieszenie, jawność i nowe myślenie; nowe myślenie w polityce zagranicznej, próba reform KPZR. Koniec rządów Gorbaczowa; rozpad imperium.

Podział ten został dokonany w sposób przemyślany, ukazując charakterystyczne bloki książki stanowiącej jednocześnie nowe i koherentne ujęcie problematyki. Całość książki składa się na dobrze uzasadniony i erudycyjny wywód krytycznie analizujący osobę Gorbaczowa, który w opisywanym okresie miał znaczący wpływ na przemiany systemowe w ZSRR w odniesieniu do uwarunkowań wewnętrznych i zewnętrznych.

Przedmiotem analizy pierwszej części książki jest bardzo interesująca analiza wpływu rodziny Michaiła Gorbaczowa na jego młodzieńczą osobowość. To właśnie miejsce urodzenia - wieś Priwolnoje w kraju Stawropolskim, jak i studia w Moskwie ukształtowały w nim wrażliwość i krytycyzm, tak istotne w jego późniejszej karierze. Warto odnotować, że Gorbaczow będąc już pierwszym sekretarzem w Kraju Stawropolskim wykazał się wyjątkowymi zdolnościami jako strateg i organizator życia politycznego a przede wszystkim gospodarczego.

Jak podkreśla Autorka pod rządami Gorbaczowa do Kraju Stawropolskiego przyjeżḋali ludzie szukający pracy i lepszego życia z innych regionów Kaukazu. Z biegiem czasu w kręgach decyzyjnych pojawiło się przekonanie, ze Gorbaczowa należy wspierać jako „,nowego , młodego szefa, który działa na skale państwowa”.

W drugiej części zatytułowanej „Próba reform: przyspieszenie, jawność i nowe myślenie" pokazano takie problemy jak; plany reform Gorbaczowa, przyspieszenie w gospodarce, Głasnost' i nowe myślenie, od mityngów do organizacji obywatelskich, w stronę religii, sprawy trudne i zapalne kwestie narodowościowe. Dziś, z perspektywy czasu, wydaje 
się, że był to najważniejszy okres w działalności Gorbaczowa, który dążył przede wszystkim do zreformowania ZSRR a nie jego rozpadu. Jego determinacja i wiara w możliwość naprawy państwa zaczynają tracić jednak na znaczeniu. Autorka publikacji słusznie zwraca uwagę, że Gorbaczow nie docenił w swoich działaniach kwestii narodowościowych (s.108-113) dlatego władza coraz wyraźniej wymykała się z jego rąk.

Należy zgodzić się z faktem, że z perspektywy czasu głasnost' i nowe myślenie okazały się najbardziej rezultatywne z reform przeprowadzonych przez Gorbaczowa, być może dlatego, że rządzący umożliwili społeczeństwu samoorganizowanie się, zniesiono cenzurę, zaczęto pod kontrolą, i coraz bardziej bez niej, wprowadzać pewne elementy demokratyzacji systemu.

Polityka każdego państwa wywiera zawsze pewien wpływ na środowisko międzynarodowe, starając się w nim ukształtować swoje interesy geopolityczne, ale i geostrategiczne. Dlatego w trzeciej części monografii możemy znaleźć problemy, które zdaniem Autorki były istotne, z punktu widzenia polityki zagranicznej Gorbaczowa. Analizie poddano takie zagadnienia, jak; USA i polityka rozbrojeniowa, Europa naszym wspólnym domem, Gorbaczow a zjednoczenie Niemiec, stosunki z europejskimi państwami satelickimi, wobec Polski.

Gorbaczow miał świadomość, że państwo radzieckie musi zerwać z dotychczasową polityką zagraniczną, a zwłaszcza z „doktryną Breżniewa”, która budziła nieufność w stosunkach międzynarodowych. Dlatego deklarowane priorytety w polityce zagranicznej Michaiła Gorbaczowa były skoncentrowane na budowę zaufania i bezpieczeństwa w świecie, likwidację zagrożeń, w tym przede wszystkim: zagrożeń nuklearnych, zagrożeń globalnych, ekologicznych, zagrożeń ze strony państw trzeciego świata - o czym pisze Autorka na wstępie trzeciej części monografii. Warto również odnieść się do spraw Polski, gdzie Autorka bardzo precyzyjnie analizuje rolę Warszawy w polityce państwa radzieckiego, jak też nakreśla istotne cechy, które pozytywnie określały kierunek suwerennej drogi rozwoju państwa polskiego.

Przedmiotem analizy czwartej części monografii to próba reform KPZR. Koniec rządów Gorbaczowa, w której analizie podjęto następujące zagadnienia; początki zmian w partii, bezwzględna walka polityczna, Zjazd Deputowanych Ludowych - początek rozpadu partii, koniec monopolu KPZR, ostatni zjazd partii. Bardzo dobra znajomość zagadnień widoczna jest w konkluzjach i uwagach Autorki, która bardzo ciekawie odnosi się do ostatniego okresu działalności Gorbaczowa. Jak podkreśla- wybór Gorbaczowa na prezydenta ZSRR przypadał na okres jego najwyższych notowań na Zachodzie, co było związane $\mathrm{z}$ polityką 
rozbrojeniową. Potwierdzają to badania przeprowadzone w krajach europejskich i Stanach Zjednoczonych. Tymczasem napięta sytuacja wewnętrzna powodowała, że w kraju poparcie dla Gorbaczowa zaczęło gwałtownie spadać (s. 175).

Ostatnia- piąta część monografii poświęcona jest Rozpadowi imperium, w której analizie poddano takie zagadnienia jak; dalsze zaostrzenie się walki politycznej, referendum. $\mathrm{Ku}$ suwerenności, pucz Janajewa. Dokładna analiza i chronologia wydarzeń tego ostatniego okresu istnienia ZSRR zasługuje na uwagę nie tylko ze względów historycznych, ale również na potrzebę ukazania mechanizmu władzy i jej uwarunkowań, zarówno wewnętrznych, jak i międzynarodowych.

W bilansie pierestrojki Autorka trafnie podkreśla, że zaplanowana przez Gorbaczowa na 20-30 lat pieriestrojka była ogromnym programem, lecz w ówczesnych warunkach okazała się projektem nierealistycznym. Ekipa Gorbaczowa rozpoczęła reformy pod hasłem modernizacji systemu, jednak bieg wydarzeń wskazywał coraz bardziej, że systemu tego nie dało się już zreformować. Pod koniec swoich rządów Gorbaczow chciał jedynie za wszelką cenę ratować jedność państwa i walczył o własną pozycję (s. 211). Wydaje się ponadto, że oprócz czynnika narodowościowego, w reformowaniu imperium radzieckiego, którego Gorbaczow nie docenił, istotnym jest aby reformy były inspirowane i realizowane oddolnie a nie na odwrót. Przykład Polski i jej „Solidarności” pokazuje, jak inicjatywy oddolne mogą skutecznie wpływać na przemiany ustrojowo-prawne i polityczne państwa, jak i na kierunek jego rozwoju.

Alicja Stępień - Kuczyńska podaje bardzo wiele interesujących i istotnych, z punktu widzenia inicjatyw społeczno-politycznych, które przeprowadzał Michaił Gorbaczow. Były to inicjatywy zarówno o charakterze wewnętrznym, jak i międzynarodowym. Dlatego warto „sięgnąć” po Gorbaczowa, aby zrozumieć ówczesny mechanizm władzy a zwłaszcza stosunek Zachodu do owych przemian $i$ ich znaczenie dla ładu międzynarodowego.

$\mathrm{Na}$ szczególną uwagę zasługuje fakt, iż książka ta jest efektem długoletniej pracy naukowej, w trakcie której odbyły się debaty i konferencje poświęcone roli Michaiła Gorbaczowa w okresie przemian systemowych w ZSRR od 1985 do 1991. Autorka opublikowała w 2016 roku książkę pt. Michait Gorbaczow a idea i praktyka pieriestrojki a jej pogłębione studia zaowocowały Gorbaczowem w 2020 roku. Tym bardziej cenne są opinie i poglądy Autorki monografii, które mogą przyczynić się do lepszego zrozumienia procesów społeczno-politycznych i gospodarczych zachodzących pod koniec istnienia ZSRR, jak i na początku przemian systemowych Federacji Rosyjskiej. 
Powyższa monografia pt. „Gorbaczow” spełnia wymogi pracy naukowej zarówno pod względem metodologicznym, jak i merytorycznym. Zawiera ona stosowne założenia, przewidziane w pracach naukowych. Należy zgodzić się z tezą, że jest to opracowanie, wypełniające lukę badawczą i poznawczą w zakresie przemian systemowych pod koniec istnienia ZSRR, jak i w pierwszym okresie kształtowania się ustroju politycznego w Federacji rosyjskiej. Jak słusznie podkreśla Autorka monografii „okres krótkich, niespełna siedmioletnich, rządów Gorbaczowa i próby reformowania przez niego systemu komunistycznego zamykają ostatni etap istnienia państwa, w którym bezwzględna władza dominowała przez dziesięciolecia nad społeczeństwami i narodami znacznej części świata, jednostki zaś pozbawiała wolności i praw do rozwoju. Pieriestrojka Gorbaczowa stanowiła impuls do otwarcia na zmiany w ZSRR i krajach satelickich" (s. 14).

Generalnie, analizy, syntezy i logika wywodów przedstawiona w recenzowanej książce jest cennym dorobkiem naukowym, ale i publicystycznym adresowanym do środowiska akademickiego, jak i osób zajmujących się procesami przemian systemowych na Wschodzie. Jest ona ważnym kompendium wiedzy o reformach podejmowanych u ,schyłku” ZSRR, którego rola i znaczenie w Europie i świecie była znacząca. 